\title{
The Notion of Power in Hans Jonas' Das Prinzip Verantwortung (The Imperative of Responsibility)
}

\author{
A noção de poder em Das Prinzip Verantwortung (O Princípio da
}

Responsabilidade) de Hans Jonas

PIOTR Rosót (iDa

\begin{abstract}
The questions concerning control over the environment are becoming increasingly more significant. From ecology to medicine, from bioethics to transhumanism, there are many different issues reflected and acted upon, which have an important common element, namely underlying premises about the relationship between the natural biosphere and humans. Hans Jonas, in his book The Imperative of Responsibility: In Search for an Ethics for the Technological Age, first published over 40 years ago in German as Das Prinzip Verantwortung: Versuch einer Ethik für die technologische Zivilisation, proposed philosophical and ethical foundations for understanding this relationship. One of the underestimated Hans Jonas' reflections concerns the characteristic of power. The paper analyzes the concept of power presented along with the imperative of responsibility, as well as three different degrees of power characteristic for Jonas' approach to the notion of power. The paper presents this structure of power and the underlying philosophical considerations that constitute a basis for it. It also provides an argument that these considerations may be used as a framework for understanding many contemporary challenges and ethical responsibility in the technological age.
\end{abstract}

Keywords: Hans Jonas. Power. Technology. Ethics of Responsibility. Philosophy of Technology.

\section{Resumo}

Questões acerca do controle do meio ambiente estão se tornando cada vez mais significantes. Da ecologia à medicina, da bioética ao transumanismo, há muitos problemas diferentes sendo refletidos e aplicados, que contêm um importante elemento comum,

\footnotetext{
a The Maria Grzegorzewska University in Warsaw, Warsaw, Poland. PhD in Philosophy, e-mail: prosol@aps.edu.pl
} 
nomeadamente as premissas subjacentes à relação entre a biosfera e os seres humanos. Hans Jonas, no seu livro O Princípio da Responsabilidade: Ensaio de uma ética para a civilização tecnológica, publicado pela primeira vez há mais de 40 anos em Alemão e com o título Das Prinzip Verantwortung: Versuch einer Ethik für die technologische Zivilisation, propõe fundamentos filosóficos e éticos para a compreensão dessa relação. Uma das reflexões subestimadas de Hans Jonas diz respeito à característica do poder. $O$ artigo analisa o conceito de poder junto com o imperativo de responsabilidade, bem como três diferentes graus de poder característicos para a abordagem da noção de poder de Jonas. O artigo apresenta essa estrutura de poder e as considerações filosóficas subjacentes que constituem a sua base. Também fornece um argumento de que essas considerações podem ser usadas como uma estrutura para a compreensão de muitos desafios contemporâneos e responsabilidade ética na era tecnológica.

Palavras-chave: Hans Jonas. Poder. Tecnologia. Ética da Responsabilidade. Filosofia da Tecnologia.

\section{Introduction}

Forty years old books in humanities and social sciences are often treated as curiosities. It is especially so if the topics they discuss change quickly and significantly. They might be an interesting read, and the author's far-fetched ideas, mistaken predictions, and failures of imagination can be perceived as preposterous and hilarious. Das Prinzip Verantwortung (JONAS, 1979) (The Imperative of Responsibility) addresses such a debated and dynamic topic, namely a new paradigm of technological influence on the human world and a new role of ethics in the world under the constant influence of technological progress and innovation. An unkind reader might read Jonas' book in this way and search for points and paragraphs that are outdated and invalid in a contemporary context. In this paper, I shall apply the opposite reading strategy and stress how the understanding of power of and over technology still needs rethinking, and how Jonas' book is relevant for contemporary challenges concerning the relationship between human beings and the biosphere.

There are many articles and books articulating the relevance of Jonas' thought for contemporary debates (see e.g. LEVY, 2002, pp. 83-84; GORDON et al., 2016, pp. 1-3). The importance of stressing the dimension of ethical responsibility for the future has also been highlighted (see e.g. SEIDEL et al., 2007; BÖHLER, 2009). This paper concentrates on the relationship between power, biosphere, and responsibility. 
Invoking Jonas' account of those issues and applying them to some contemporary examples provides further justification for reading and rereading Jonas in contemporary contexts.

The paper is structured in the following way: a description of Jonas' concept of three degrees of power, a comparison of Jonas and Hegel's understanding of technology, some reflections about an unconscious and conscious understanding of the co-dependencies between humans and technology, some examples of the role of responsibility in current debates about environmental and bioethical challenges.

\section{Three Degrees of Power}

In my discussion, I will concentrate on one particular issue raised in The Imperative of Responsibility that is a vivid illustration of the actual character of problems described by Jonas, namely, the problem of control over technological progress and the distinction between three levels of power over nature. In Jonas' own words, the relationship between those three levels can be described in the following way:

The power has become self-acting, while its promise has turned into threat, its prospect of salvation into apocalypse. Power over the power is required now before the halt is called by catastrophe itself - the power to overcome that impotence over against the selffeeding compulsion of power to its progressive exercise. After the first-degree power, directed at a seemingly inexhaustible nature, has changed into a second-degree power which wrested control of the first from the user's hands, it is now up to a third degree power to enforce the self-limitation of the rule that carries along the ruler, before it shatters on the barriers of nature. This third degree means power over the second-degree power, which was no longer man's but power's itself to dictate its use to its supposed owner and to make of him the compulsive executor of his capacity, thus enslaving man instead of liberating him (JONAS, 1984, pp. 141-142).

The first-degree power is devoted to influencing immediate surroundings. It is not limited to humans but shared with other living beings. The extent of this power varies dramatically from bacterias to humans. There is, however, a substantial common element, namely the possibility of interacting with and having an impact on the environment. These capabilities constitute the first level of power. This approach resembles Jonas' reflection on the first degree of freedom; freedom that is already 
present in the simplest living organisms and relies on metabolism as its fulfilment (JONAS, 2016; DONNELLEY, 1978, p. 162).

On the second level of power appears the possibility of using instruments tools mediating between an agent and the environment. This mediation reinforces possible clout of beings using it. The second-degree power is present in the activities of some animals, including humans. The second-degree power available to living beings is very limited and is imputable to some animals capable of building their habitats (from corals to ants), as well as the species able to use very simple tools (from orangutans to dolphins). I mention this continuity in living beings able to use the second-degree power because an essential part of Jonas' metaphysical position consists in stressing the continuous character of the development of living organisms (JONAS, 2016).

From Jonas' point of view conveyed in The Imperative of Responsibility, as well as of this paper, the third-degree power is crucial for ethics and thus for political and social life. It means power not over the closest environment, nor over the mediations of power that allow influencing the environment, but a reflective attitude towards the second-degree power. At the same time, we need to remember that understanding the third-degree power is possible only after acquiring knowledge about the seconddegree one. The third-degree power comes to light thanks to scrutiny and reasoning about the influences of technology.

\section{The Dialectics of Power over Nature}

The dialectics of power over nature mentioned by Jonas means dialectics in the modern, not Aristotelian sense. It is not about the art of argumentation and discussion, but about the relationship between power, its object, and realization of it. Although Jonas does not mention Georg Hegel directly, in order to understand his position, it is worth considering Hegel's attitude towards power and technology. Natalia Juchniewicz, while analyzing dialectics of technology in Hegel's thought, states: 
According to Hegel, we can schematically write the dialectics of technological artefacts as going from the body to the machine: body $\rightarrow$ tool $\rightarrow$ machine. It means that the human being has a natural equipment of bodily abilities, which can be externalized by using tools. Tools mediate the relation between subject and nature and move away from the possibility to fulfil the needs immediately. Work done with the use of tools becomes more abstract and, as a result of such mediated activity, it is possible to create the machine as an object that works instead of the man (JUCHNIEWICZ, 2018, p. 825).

The body and the tool in Hegel's position would correspond with the firstdegree power in Jonas' theory. The machine would resemble the second-degree power, the moment in which power over nature begins to gain independence from its maker. The third-degree power is the main difference between Hegelian and Jonasian dialectics of technology. According to Juchniewicz, Hegel seeks the solution enabling the decrease of the instrumentalizing influence of technology in the sphere of law and state (JUCHNIEWICZ, 2018, p. 828). Jonas searches for the possibility of regaining control over the machine in philosophical and ethical reflections. Those can be internalized into laws and implemented by the state institutions only after conscious reflection about the influence technology exerts on us. At the same time, it is possible to claim that those machines that help to realize the imperative of responsibility and those that make it easier to regain control over technological progress are good. Those devices and discoveries that are influencing human beings to act against the imperative of responsibility and those that are making it more difficult to control technological changes are evil. This seems to be far from Hegel's understanding of ethics as ethos and analyzing technology in a context of culture and tradition without using ethical categories of good and evil (see JUCHNIEWICZ, 2018, p. 827).

It is worthwhile to emphasize that in both, Hegel's and Jonas' dialectics, the process of regaining control over the machine/uncontrolled development of technology is not some desperate moving "back to nature," as it is the case in Rousseau's and his interpreters' theories (LEVY, 2002, pp. 86-88). It is neither a kind of agreement with the inevitability of the rule of the machine. They both believe in the possibility of human freedom, freedom of establishing human purposes, and striving to realize them; for both of them, the purposiveness of human beings is a crucial element of recognizing the value of humanity. They both believe in the 
possibility of an unalienated relationship between humans and technology (VOGEL, 2008, p. 9).

\section{The Power of Technology - (Un)Awareness of the Third-Degree Power}

Jonas remarks that the development of second-degree power gains its own dynamics. The more power humans can use, the more the way of mediating this power matters. Also, the bigger the power, the higher the risk of it getting out of control. Lack of awareness of the possibility of influencing the environment does not defend from the perils and risks of those influences. It is like closing your eyes in order to avoid the danger.

Developing a particular technology starts chains of causes and effects that might lead to self-propelling processes. A similar dynamic of causes and effects that can easily get out of human control can be observed in the case of animal introduction and other human attempts of influencing ecosystems (TENNER, 1997).

This third level of power is characteristic for humans. Animals are unable to reflect upon the tools they use and weigh the pros and cons of their reflexive influence. It is worth mentioning that the discussion about the role of the seconddegree power and the possibility of the existence of the third-degree power is ongoing, and the need for the latter is stressed in contemporary literature about social and political aspects of technology. For example, Andrew Feenberg remarks that:

In the case of environmentalism, for example, this has to do with responsibility for environmental problems. If they are attributed to the ill will of powerful individuals, or worse yet to bad decisions by consumers, the role of technology is minimized. In reality technology is the main culprit and no serious advance can be made without changing it. That requires more than a change of personnel or attitude since engineers and other technical workers act in accordance with technical disciplines. Those disciplines codify the impersonal power of technology in conformity with hegemonic social demands. If the problems are not addressed at that level, they cannot be solved (FEENBERG, 2017, p. 193).

In the language of power-degrees proposed by Jonas, we can translate this fragment into an observation that the lack or underestimation of the role of third- 
degree power over technologies leads to over-estimating the role of actualizations of the second-degree power. Thus, there is both philosophical and political need for the third-degree power of and over technology. It will allow us to understand the role of technology in the time of environmental crisis, as well as consciously and effectively search for solutions to arising problems. Without the third-degree power over technological progress, we are unable to comprehend what the problems and looming dangers are. Since without reflection upon the possibilities of influencing the results of technological developments, we do not understand which part of the social and political process will be the most influential upon the realization of a particular technology. Therefore, it is probable that we would blame people or practices from the wrong level of interaction, and in consequence expect wrong actors to take responsibility and undertake restorative intervention (REES, 2003, pp. 58-60).

Frank Pasquale describes the problem of treating technology as a black-box, $\mathrm{i}$. e. something we cannot control and that conceals values and decisions about important factors by hiding them in seemingly neutral and technical algorithms and solutions (PASQUALE, 2015). In Jonas' language, such a state of affairs establishes a new form of relations between the second and the third degree of power. The lack of awareness of the third-degree power is maintained and instrumentalized to avoid discussion about the way technology works on both the second and third degrees of power.

\section{Responsibility and Power}

The issue of power and control over technology is strongly connected with the question of ethical responsibility. Both techno-enthusiastic and techno-pessimistic attitudes are prone to absolving humans from responsibility for actions concerning technological progress and its Janusian face. If we claim that technological progress is inevitable, and we need to submit ourselves to its power, as well as exclude the possibility of directing it, it becomes impossible to ascribe responsibility for its consequences. The difference between the description of the inevitability of technological change as progress (KELLY, 2010) or regress (ELLUL, 1964) is much 
smaller than the ongoing discussion between those two broadly understood attitudes might suggest. In both cases, we are lacking control over what is happening with technology in our societies. We are only able to manipulate and influence our attitudes towards those changes. Like the hero in Nietzsche's story about eternal recurrence, who needs to answer the question regarding his emotional reaction, either joy or despair, that will accompany him till the end of his life, of which he is aware because he has learnt that his life, in this form, will be repeating itself indefinitely (NIETZSCHE, 1974, pp. 273-274).

Hans Jonas' considerations written down in The Imperative of Responsibility might present us with a possible conceptual framework for a reflection about regaining control over technological development and taking responsibility that accompanies it. Jonas' imperative and its metaphysical justification brings a possibility of concluding from the answer to the question: "what is there?" ethically justified answers to the question "what ought to be?" (WOLIN, 2015, pp. 118-119). Equipped with that knowledge, we will be able to respond more adequately to many challenges of the contemporary world and deny the self-sufficient character of technological development. It is important to remember that the possibility of making a choice will bring with it also the possibility of making wrong choices. The way we respond to pollution, inequality, pandemic, climate crisis, and many other contemporary social and political threats do include questions about the relationship between humans and nature (see e.g. The Economist, 2020, pp. 47-48; ULRICH, 2020). Therefore, our responses include the issues concerning all three degrees of power described above.

An account of Jonas thought might also be an argument against the following statement:

A number of famous bioethicists who move to the field of transhumanism do not mean that there is a necessary link between these two areas. They are relatively separate and can operate as such. Bioethics is conducted within a realistic worldview and should keep a clear distance to a kind of idealistic worldview present in transhumanism. It means that in the centre of bioethics is the human reality, which we discover and deal with right now, whereas in the centre of attention of transhumanism is the projection of whom the human being can become in the future (HOŁUB, 2020, p. 71).

The assumed distance between transhumanism and bioethics does not take into consideration the reflections about the three degrees of power. Developing 
technologies directed at overcoming humanity will have an inner dynamic and might be influencing, in a reflexive way, our self-understanding as a species. In other words, those technologies will be impacting reality on the second-degree of power treating humanity and particular human beings as something that can be changed according to some transhumanist standards, for example understanding human being with the use of the extended minds hypothesis (PEDACE et al., 2020, p. 129- 130). They will include second-degree power of inner logic of those developments, as well as some third-degree power directed at the realization of transhumanistic ideals about humanity.

Bioethicists, ignoring those interdependencies and claiming that the future of human species does not need to be included in their reflection, are risking the occurrence of the situation where their perspective will become obsolete, as developments of new transhumanist technologies will be out of limits of bioethical rules and values. In fact, we do not need to wait for such future developments. Already existing technologies, which are present in bioethical aspects of human life are also a part of second- and third-degree power struggles and are already a part of different causal relationships influencing the way we understand life and death (see e.g. GIOVANNI, 2017; VEERBEK, 2011, pp. 26-27).

A constant rereading of The Imperative of Responsibility other Jonas' works in a new technological context discloses the need for a reflection on different ways of influencing the reality, different degrees of human power, the differences in possible attitudes towards the biosphere (LATOUR, 2017). Moreover, it may provide an ontological and ethical framework that would allow us to understand what should be allowed and what should be forbidden. Jonas describes the connection between the ability to act and be responsible for those acts in the following way:

Power conjoined with reason carries responsibility with it. This was always self-understood in regard to the intrahuman sphere. What is not yet fully understood is the novel expansion of responsibility to the condition of the biosphere and the future survival of mankind, which follows simply from the extension of power over these things and from its being eminently a power of destruction. Power and peril reveal a duty which, through the commanding solidarity with the rest, extends from our being to that of the whole, regardless of our consent (JONAS, 1976, p. 80). 
In this quote, Jonas vividly calls our attention to the relationship between power and responsibility. By gaining the possibility of influencing the world in a deep sense, our responsibility expands proportionally. In order to be conscious about our capabilities, mediating roles of different technologies, and ethical responsibilities connected to their applications, we need to fully understand different degrees of available power. Having conceived the possible actions and their consequences, we will fully understand and take responsibility for them. Rereading Jonas can be a beneficial lesson for the constant process of expanding power, a lesson that would enable carrying it out with a proper level of responsibility.

\section{Conclusion}

The first-degree power is for Jonas an important aspect of human existence that connects us with the environment and other living beings. Already on this first degree of freedom, many tensions arise that are characteristic for actualizing themselves human beings, and are visible on many levels of life. The first interplays between necessity and freedom that are present already on this level (JONAS, 2016). The second degree includes the mediation of human actions in the world with the usage of broadly understood tools - tools that have a tendency to autonomize themselves, to obtain tendencies incorporated in themselves (VEERBEK, 2011). By understanding those tendencies, as well as by understanding that a possibility of doing something does not establish justification for doing it, we can avoid some of the negative aspects of the dialectics of power. The dialectics that often leads to the situation where new powers are actually used to control others. More power for some leads to less freedom for many (PASQUALE, 2015). Only reflection might enable the third degree of power. It would allow us to act responsibly, to better understand the limitations of our powers, to "Act so that the effects of your action are compatible with the permanence of genuine human life. (...) not compromise the conditions for an indefinite continuation of humanity on earth" (JONAS, 1984, p. 11). 


\section{References}

BÖHLER, D., Zukunftsverantwortung in Globaler Perspektive. Zur Aktualität von Hans Jonas und der Diskursethik, Bad Homburg: VAS, 2009.

DONNELLEY, S., Whitehead and Jonas: on biological organisms and real individuals. In: Organism, Medicine and Metaphysics. Essays in Honor of Hans Jonas on his 75-th Birthday, ed. by S. F. Spicker, Dordrecht: D. Reidel Publishing Company 1978.

ELLUL, J., Technological society. Toronto: Vintage Book, 1964.

FEENBERG, A., Technosystem. The Social Life of Reason. Cambridge: Harvard University Press, 2017.

GIOVANNI, M., Essays in medical ethics. Plea for a Medicine of Prudence, Stuttgart: Thieme 2017.

GORDON, J.-S., BURCKHART, H., SEGLER, P., Introduction. In: Global Ethics and Moral Responsibility. Hans Jonas and his Critics, ed. by GORDON, J.-S., BURCKHART, H., New York: Routledge 2016.

HOŁUB, G., Is Transhumanism a New Face of Bioethics?, Rev. Filos., Aurora, Curitiba, v. 32, n. 55, pp. 62-73, jan./abr. 2020.

JONAS, H., Das Prinæip Verantwortung. Versuch einer Ethik für die technologische Zivilisation. Frankfurt am Main: Suhrkamp 1979.

JONAS, H., Organism and Freedom. An Essay in Philosophical Biology. ed. J. Becker, F. Preußger, Siegen 2016. Available online: http://hans-jonas-edition.de/wpcontent/uploads/2016/10/KGA_Hans-Jonas-Kontext-Bd.-I1-Organism-and-Freedom.pdf

JONAS, H., Responsibility Today: The Ethics of an Endangered Future, Social Research, Vol. 43, No. 1, (SPRING 1976), pp. 77-97.

JONAS, H., The Imperative of Responsibility. In Search for an Ethics for the Technological Age. Chicago: The University of Chicago Press, 1984.

JUCHNIEWICZ, N., Dialectical Technology - Hegel on Means, Tools and the Machine, FILOZOFIA 73, 2018, No. 10, pp. 818 - 830. Available online: http://www.klemens.sav.sk/fiusav/doc/filozofia/2018/10/818-830.pdf

KELLY, K., What technology wants? New York: Viking, 2010.

LATOUR, B., Facing Gaia. Eight Lectures on the New Climatic Regime, trans. C. Porter, Cambridge: Polity 2017/

LEVY, D., Hans Jonas: The Integrity of Thinking, Columbia: University of Missouri Press, 2002.

NIETZSCHE, F., The Gay Science, trans. W. Kaufmann, New York: Vintage Books 1974.

PASQUALE, F., The Black Box Society. The Secret Algorithms that Control Money and Information, Massachusetts: Harvard University Press 2015. 
PEDACE, K., BALMACEDA T., LAWLER D., PEREZ, D., ZELLER, M., Natural Born Transhumans, Rev. Filos., Aurora, Curitiba, v. 32, n. 55, p. 112-131, jan./abr. 2020.

Prin₹ip Zukunft. Im Dialog mit Hans Jonas, ed. SEIDEL, R., ENDRUWEIT M., Borchen: Mentis 2007.

REES, M., Our Final Hour. A Scientist's Warning: How Terror, Error, and Environmental Disaster Threaten Humankind's Future in This Century - On Earth and Beyond, New York: Basic Books, 2003.

TENNER, E. Why Things Bite Back: Technology and the Revenge of Unintended Consequences. Vintage 1997.

The Economist, May 9-th 2020, Where nature ends. Carbon cycles, p. 47, 48.

ULRICH, B., Wo sind die Grünen, wenn man sie mal braucht?, Die Zeit 31.05.2020.

VERBEEK, P., Moralizing Technology. Understanding and Designing the Morality of Things, Chicago: The University of Chicago Press 2011.

VOGEL, L., The Responsibility Of Thinking In Dark Times: Hannah Arendt Versus Hans Jonas, Graduate Faculty Philosophy Journal 29.1 (2008): 253-293. Web.

WOLIN, R. Heidegger's Children: Hannah Arendt, Karl Löwith, Hans Jonas, and Herbert Marcuse, Princeton: Princeton University Press 2015. 